Available online on 15.09.2020 at http://ujpr.org
Universal Journal of Pharmaceutical Research
An International Peer Reviewed Journal
Open access to Pharmaceutical research
Commercial Share Alike 4.0 License which permits unrestricted non commercial use,
provided the original work is properly cited
Volume 5, Issue 4, 2020

\title{
LONG CHAIN POLYMERIC CARBOHYDRATE DEPENDENT NANOCOMPOSITES IN TISSUE ENGINEERING Muhammad Shahzad Aslam
}

School of Traditional Chinese Medicine, Xiamen University Malaysia, Jalan Sunsuria, Bandar Sunsuria, 43900 Sepang, Selangor

\section{ABSTRACT}

The use of nanomedicine has increased enormously, especially in the field of gene delivery and targeted drug delivery. The objective of current review to identify long-chain polymeric carbohydrate dependent nano-composites in tissue engineering such gellan gum incorporated $\mathrm{TiO}_{2}$ nanotubes, Poly(vinyl) alcohol-gellan gum-based nanofiber, cross-linked gellan/pva nanofibers, nanocellulose reinforced gellan-gum hydrogels, dextran and sol-gel derived bioactive glass-ceramic nanoparticles, aminated $\beta$-cyclodextrin-modified-carboxylated magnetic cobalt/ nanocellulose composite, chitosan-chitin nanocrystal composite scaffolds, sodium alginate-xanthan gum-based nano-composite scaffolds, nano-hydroxyapatite pullulan/dextran polysaccharide composite, chitosan/carbon nanofibers scaffolds, nano-bio composite scaffold of chitosan-gelatin-alginatehydroxyapatite, alginate/gelatin scaffolds with homogeneous nano apatite coating, nano-hydroxyapatite-alginate-gelatinmicrocapsule, poly( $\varepsilon$ caprolactone)/keratin nano fibrousmats, keratin nanoparticles-coating electrospun PVA nanofiber, nano-hydroxyapatite/chitosan/chondroitin sulfate/hyaluronic acid and chitosan/chondroitin sulfate/nano-bioglass. The current review has identified a list of medicinal herbs that have been incorporated into long chain polymeric carbohydrate-based nano-composites.

Keywords: Nano-composites, nanomedicine, polymeric carbohydrate.

Article Info: Received 15 June 2020; Revised 23 July; Accepted 28 August, Available online 15 September 2020

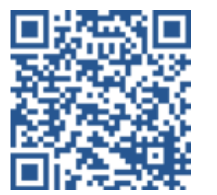

Cite this article-

Aslam MS. Long chain polymeric carbohydrate dependent nanocomposites in tissue engineering. Universal Journal of Pharmaceutical Research 2020; 5(4):65-70.

DOI: https://doi.org/10.22270/ujpr.v5i4.441

Address for Correspondence

Dr. Muhammad Shahzad Aslam, School of Traditional Chinese Medicine, Xiamen University Malaysia, Jalan Sunsuria, Bandar Sunsuria, 43900 Sepang, Selangor, Tel: +60 19-300 9674, E-mail: aslam.shahzad@xmu.edu.my

\section{INTRODUCTION}

Nanomedicine has gained a lot of interest due to its vast application. Physical and chemical attributes of nanomaterials have lengthened its application in the field of biological science and biomedical engineering such as biological imaging, drug delivery, biomolecular sensing, and Infectious Diseases ${ }^{1}$. There are different types of nanomaterials such as Inorganic nanomaterials (Graphene, mesoporous silica, gold, magnetic, quantum dots, and layered double hydroxides) and metal-organic frameworks (Zirconium -based metal-organic frameworks, Lanthanide-Based Metal-Organic Frameworks, Oligo nucleotideFunctionalized Metal-Organic Framework) ${ }^{2,3}$. Inorganic nano materials possess intrinsically physicochemical properties and good biocompatibility, as a result, they are used in different applications such as bio imaging, targeted drug delivery, and cancer therapies, whereas the Metal-organic framework is porous hybrid polymer-metal composites ${ }^{4,5}$. They possess many biomedical applications due to their excellent porosity, high loading capacity, biodegradebility, and ease of surface modification when compared to others ${ }^{6,7}$.
The selection of material depends upon the biological activity, biocompatibility, and biodegradability. The materials provide an analogous environment to the extracellular matrix (ECM) and provide an induced rate of synthesis or growth of new tissues. Extracellular matrix consists of collagen fibril, glycoproteins such as fibronectin and laminin for attachment. In addition to the extracellular matrix, connective tissues are characterized by fibroblasts and ground substances which are usually fluid, but it can also be mineralized and solid, as in bones ${ }^{8}$. Polysaccharides offer a green alternative to synthetic polymers in the preparation of soft nanomaterials ${ }^{9}$. Monosaccharides and disaccharides are bonded through covalent linkage to develop a long chain of polymer-based carbohydrates. They also consist of other functional groups such as pyruvate, sulfate, and methyl. They can range from linear to branched structure. A list of bacterial polysaccharides consists of the intracellular, capsular, or exo-based skeleton. Exo based polysaccharides are Dextran, alginate, hyaluronic acid, and xanthan, which are synthesized extracellularly by cell wall-anchored enzymes $^{10,11,12}$. 
Table 1: Long chain polymeric Carbohydrate dependent nano-composites in tissue engineering.

\begin{tabular}{|c|c|c|c|c|}
\hline No. & Material Composition & $\begin{array}{c}\text { Characterization } \\
\text { Techniques }\end{array}$ & Application & $\begin{array}{l}\text { In-vitro/in-vivo Testing } \\
\text { relevant to TE and GD }\end{array}$ \\
\hline 1. & 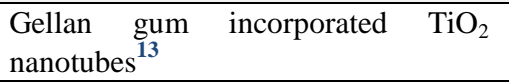 & $\begin{array}{l}\text { FTIR, XRD } \\
\text { and SEM }\end{array}$ & $\begin{array}{l}\text { Skin tissue } \\
\text { engineering }\end{array}$ & $\begin{array}{l}\text { Cell viability and proliferation } \\
\text { testing }\end{array}$ \\
\hline 2. & $\begin{array}{l}\text { Poly (vinyl) alcohol-gellan gum based } \\
\text { nanofiber }{ }^{16}\end{array}$ & SEM and FTIR & 3D nanofibrous scaffold. & $\begin{array}{l}\text { In-vitro embryonic stem cells } \\
\text { (ESCs) }\end{array}$ \\
\hline 3. & Cross-linked gellan/PVA nanofibers ${ }^{18}$ & FESEM & $\begin{array}{l}\text { Human dermal fibroblast } \\
\text { (3T3L1) cells in tissue } \\
\text { engineering application }\end{array}$ & $\begin{array}{l}\text { Cell proliferation behaviour of } \\
\text { human dermal fibroblast cells } \\
(3 T 3 L 1)\end{array}$ \\
\hline 4. & $\begin{array}{l}\text { Nanocellulose reinforced gellan-gum } \\
\text { hydrogels }\end{array}$ & TEM & $\begin{array}{l}\text { Annulus fibrous tissue } \\
\text { regeneration }\end{array}$ & Bovine annulus fibrosus culture \\
\hline 5. & $\begin{array}{l}\text { Dextran and sol-gel derived bioactive } \\
\text { glass ceramic nanoparticles }\end{array}$ & FESEM, SEM & Bone tissue engineering & $\begin{array}{l}\text { Normal human osteoblasts } \\
\text { (HOB) Cells, } \\
\text { Cell viability assay }\end{array}$ \\
\hline 6. & $\begin{array}{l}\text { Aminated } \beta \text {-Cyclodextrin-Modified- } \\
\text { Carboxylated Magnetic } \\
\text { Cobalt/Nanocellulose Composite }^{21}\end{array}$ & $\begin{array}{l}\text { FTIR, XRD, SEM, } \\
\text { ESR }\end{array}$ & $\begin{array}{l}\text { Tumor Targeted Gene } \\
\text { delivery }\end{array}$ & $\begin{array}{l}\text { DNA Binding Studies, MTT } \\
\text { cytotoxicity assay, in vitro gene } \\
\text { transfection and gene expression } \\
\text { experiments. }\end{array}$ \\
\hline 7. & $\begin{array}{l}\text { 3D Bioprinting of iPS Cells in a } \\
\text { Nanocellulose/Alginate Bioink }\end{array}$ & $\begin{array}{l}\text { Confocal images, } \\
\text { Fluorescence } \\
\text { microscopy }\end{array}$ & \begin{tabular}{lr} 
Bioprintingi & \multicolumn{1}{c}{ PSCs to } \\
support & cartilage \\
production in & co-cultures \\
with & irradiated \\
chondrocytes & \\
\end{tabular} & $\begin{array}{l}\text { Immuno histochemical analysis, } \\
\text { Microscopy, Gene expression } \\
\text { assays }\end{array}$ \\
\hline 8. & $\begin{array}{l}\text { Chitosan-chitin nanocrystal } \\
\text { composite scaffolds }{ }^{39}\end{array}$ & SEM, XRD & Bone tissue engineering & Cell adhesion and proliferation \\
\hline 9. & $\begin{array}{l}\text { Sodium alginate-xanthan gum based } \\
\text { nano-composite scaffolds }\end{array}$ & FESEM & Bone tissue engineering & Cell viability \\
\hline 10. & $\begin{array}{l}\text { Nano-hydroxyapatite } \\
\text { Pullulan/dextran polysaccharide } \\
\text { composite }^{\mathbf{4 1}}\end{array}$ & ESEM & $\begin{array}{l}\text { Orthopaedic } \\
\text { maxillofacial } \\
\text { applications. } \\
\end{array}$ & $\begin{array}{l}\text { Experimental models performed } \\
\text { in rat and goat }\end{array}$ \\
\hline 11. & $\begin{array}{l}\text { Chitosan/Carbon nanofibers } \\
\text { Scaffolds }\end{array}$ & SEM & $\begin{array}{l}\text { Cardiac } \\
\text { Engineering }\end{array}$ & $\begin{array}{lr}\text { Culture of Neonatal } & \text { Rat } \\
\text { Cardiomyocytes, } & \text { Gene } \\
\text { Expression } & \\
\end{array}$ \\
\hline 12. & $\begin{array}{l}\text { Nano-bio composite scaffold of } \\
\text { chitosan-gelatin-alginate- } \\
\text { hydroxyapatite }^{42}\end{array}$ & ESEM & Bone tissue-engineering & $\begin{array}{l}\text { In vitro cell culture using } \\
\text { osteoblast cell line, Cell } \\
\text { viability, proliferation and } \\
\text { attachment over the scaffold, } \\
\text { Gene expression study, RNA } \\
\text { extraction study }\end{array}$ \\
\hline 13. & $\begin{array}{l}\text { Alginate/gelatin scaffolds with } \\
\text { homogeneous nano apatite coating }\end{array}$ & SEM, EDS & Bone tissue engineering. & $\begin{array}{l}\text { Proliferation and differentiation } \\
\text { of cells on scaffolds The }\end{array}$ \\
\hline 14. & $\begin{array}{l}\text { Nano-hydroxyapatite-alginate-gelatin } \\
\text { microcapsule }\end{array}$ & & $\begin{array}{l}\text { Modular bone tissue } \\
\text { engineering }\end{array}$ & Osteogenesis activity \\
\hline 15. & $\begin{array}{l}\text { Poly }(\varepsilon \text {-caprolactone)/keratin } \\
\text { nanofibrous mats }\end{array}$ & SEM & $\begin{array}{ll}\text { Vascular } & \text { tissue } \\
\text { engineering } & \\
\end{array}$ & $\begin{array}{l}\text { Fibroblast viability assay, Cell } \\
\text { attachment }\end{array}$ \\
\hline 16. & $\begin{array}{l}\text { Keratin nanoparticles-coating } \\
\text { electrospun PVA nanofiber }\end{array}$ & SEM & Neural tissue applications & $\begin{array}{l}\text { Cell morphology, adhesion and } \\
\text { proliferation }\end{array}$ \\
\hline 17 & $\begin{array}{l}\text { Nano/hydroxyapatite/chitosan/chondr } \\
\text { oitin sulfate/hyaluronic acid }\end{array}$ & SEM & Bone tissue engineering & Cell biocompatibility \\
\hline 18 & $\begin{array}{l}\text { Chitosan/chondroitin sulfate/nano- } \\
\text { bioglass } 48\end{array}$ & $\begin{array}{l}\text { XRD, FT-IR, FE- } \\
\text { SEM and TEM. }\end{array}$ & Bone tissue engineering & $\begin{array}{l}\text { In-vivo bone regeneration study, } \\
\text { In-vitro cell study }\end{array}$ \\
\hline
\end{tabular}

Ismail et al., prepared gellan gum incorporated $\mathrm{TiO}_{2}$ nanotubes using the solvent casting method for skin tissue engineering. $\mathrm{TiO}_{2}$ nanotubes are a promising tool for cell growth and proliferation for wound healing ${ }^{13}$. They are biocompatible osseointegration ${ }^{14}$ and attenuate inflammatory mediators ${ }^{15}$. Aadil et al., formulate poly(vinyl) alcohol-gellan gum-based nanofiber using electrospinning and found promising 3D nanofibrous scaffolds for various tissue engineering applications ${ }^{16}$. Poly (d, 1-lactide-co-glycolide acid) (PLGA) nanofiber is an alternative biodegradable polymer when compared with polysaccharide-based nanofiber, which is used in medical devices and drug delivery applications ${ }^{17}$. Gellan and PVA cross-link nanofiber is prepared to enhance the physicochemical stability and made biocompatible to human dermal fibroblast (3T3L1) cells ${ }^{18}$. Cellulose nanocrystals offer to aggrandize Cytocomp-atibility and improved mechanical properties as compared to carbon or metallic nanotubes ${ }^{19}$. Nanocellulose reinforced gellangum hydrogelsare helpful in Annulus fibrosus (AF) defects such as annular tears, herniation, and discectomy ${ }^{20}$. Nanocellulose Composite for also useful in the tumor-targeted gene delivery. 
Anirudhan and Rejeena have developed a novel nonviral gene vector consists of aminated b-cyclodextrin modified carboxylated magnetic cobalt/nanocellulose composite, which helps reduce the toxicity but also increased the transgene expression level ${ }^{21}$. Yvette and co-researcher also worked on nanocellulose based gene delivery and designed polyelectrolyte layer assembly of bacterial nanocellulose whiskers with plasmid $\mathrm{DNA}^{22}$. Nguyen et al., developed nanocellulose/ alginate Bioink for 3D Bioprinting of iPS Cells. The result suggests supporting cartilage production in cocultures with irradiated chondrocytes ${ }^{23}$. The other researcher also supports the evidence for the development of 3D bioprinting using nanocellulose such as 3D bioprinting of human chondrocyte-laden nanocellulose hydrogels for patient-specific auricular cartilage regeneration ${ }^{24}$, wood-based nanocellulose and bioactive glass modified gelatin-alginate bioinks for $3 \mathrm{D}$ bioprinting of bone cells ${ }^{25}$ and development of nanocellulose-based bioinks for 3D bioprinting of Soft Tissue. The problem in all the above research lacks pre-clinical and clinical trials. This leads to motivation for researchers to design a randomized double-blind clinical trial for future commercial prospective. Dextran based hydrogel is prevalent in a different kind of tissue repair such as cartilage tissue engineering ${ }^{26}$, vascular tissue engineering ${ }^{27}$, bone tissue engineering $^{28}$, skin tissue engineering, ${ }^{29}$, wound repair $^{30}$. Nikpour and their co researcher-developed Dextran based bioactive glass-ceramic nano-composite scaffold. They synthesized nano bioactive glassceramic particles (nBGC) by sol-gel method, whereas the chemical cross-linked technique is used for the preparation of the nano-composite scaffold. They identify silicon dioxide improves surface reaction to contact with body fluids, and develops active surface area for in vitro/vivo bone tissue engineering ${ }^{31}$. Some important Polysaccharide-based Nano-composites for tissue engineering and gene delivery are mentioned in Table 1. The researcher excluded several nanocomposite as of lack of available literature on in-vitro or in-vivo evaluation. Chitosan-based biomaterial has been well known for the preparation of nontoxic, biodegradable, and biocompatible polysaccharide of $\beta(1-4)$-linked d-glucosamine and N-acetyl-dglucosamine $^{32}$. Chitosan has been used to prepare collagen/chitosan porous scaffolds ${ }^{33}$, injectable chitosan-based hydrogels ${ }^{34}$, chitosannanohydroxyapatite composite scaffolds ${ }^{35}$, chitin-based tubes $^{36}$, chitosan-alginate hybrid scaffolds ${ }^{37}$, and chitosan/carbon scaffolds ${ }^{38}$.

Table 2: Some medicinal herbs incorporated into long-chain polymeric carbohydrate-based nano-composites for tissue regeneration.

\begin{tabular}{|c|c|c|}
\hline Medicinal Herb & $\begin{array}{l}\text { Polysaccharides based Nano- } \\
\text { composites }\end{array}$ & Application \\
\hline Lycium barbarum $^{52}$ & $\begin{array}{l}\text { Lycium barbarum polysaccharide } \\
\text { encapsulated Poly lactic-co- } \\
\text { glycolic acid Nanofibers }\end{array}$ & $\begin{array}{l}\text { Peripheral nerve } \\
\text { tissue engineering }\end{array}$ \\
\hline $\begin{array}{l}\text { Elaeagnus } \\
\text { angustifolia }^{54}\end{array}$ & $\begin{array}{l}\text { EA extract was loaded onto } \\
\text { poly( }(\varepsilon-\text {-caprolactone)- } \\
\text { poly(ethylene glycol)-poly( } \varepsilon \text { - } \\
\text { caprolactone) (PCL-PEG- } \\
\text { PCL/EA) nanofibers }\end{array}$ & $\begin{array}{l}\text { Bone tissue } \\
\text { engineering }\end{array}$ \\
\hline $\begin{array}{l}\text { Aloe barbadensis } \\
\text { miller }^{55}\end{array}$ & $\begin{array}{l}\text { Aloe vera incorporated poly( }(\varepsilon- \\
\text { caprolactone)/gum tragacanth } \\
\text { nanofibers }\end{array}$ & Wound dressing \\
\hline $\begin{array}{l}\text { Stryphnodendron } \\
\text { adstringens }^{55}\end{array}$ & $\begin{array}{l}\text { PVA/pineapple } \\
\text { nanofibers/Stryphnodendron } \\
\text { adstringens }\end{array}$ & $\begin{array}{l}\text { Medical } \\
\text { Application }\end{array}$ \\
\hline
\end{tabular}

2. Medicinal herbs incorporated into long-chain polymeric carbohydrate-based Nano-composites

Plants are the essential foundation of medicine. Some essential drugs that are still in use today are derived from traditional medicinal herbs ${ }^{49}$. Functional polysaccharides have a wide variety of application in the field of biomedical engineering and tissue repair ${ }^{50}$. Several medicinal herbs such as Indigofera aspalathoides, Azadira chtaindica, Memecylonedule and Myristica andamanica, along with a biodegradable polymer, polycaprolactone has been used in combination for skin tissue engineering ${ }^{51}$. Table 2 represents some of the medicinal herbs that are used in combination with polysaccharides based Nanocomposites. Lycium barbarum polysaccharides have encapsulated Poly lactic-co-glycolic acid Nanofibers is indicated for peripheral nerve tissue engineering ${ }^{52}$.
Elaeagnus angustifolia is traditionally indicated in osteoarthritis ${ }^{53}$. Elaeagnus angustifolia extract was loaded in poly( $\varepsilon$-caprolactone)-poly (ethylene glycol)poly( $\varepsilon$-caprolactone) (PCL-PEG-PCL/EA) nanofibers for bone tissue engineering ${ }^{54}$. Aloe vera is incorporated in poly ( $\varepsilon$-caprolactone)/gum tragacanth nanofibers to develop the wound dressing ${ }^{55}$. Stryphnodendron adstringens is indigenous to Brazil and a well-known wound healing herb on the eastern coast of South America $^{56}$. It has been used in combination with Polyvinyl alcohol and pineapple nanofibers for medical applications ${ }^{57}$.

3. Clinical trials of long-chain polymeric carbohydrate-based Nano-material

Limited available literature on the clinical trial of polysaccharides based Nano-material. Although several material is available and examined in-vitro or in-vivo a very few materials went for the clinical trial. Most of 
the available literature does not seem able to proceed further for clinical trials. A pilot randomized clinical trial of a customized nanotextile wet garment treatment was performed on moderate and severe atopic dermatitis and found useful in the treatment of eczema $^{58}$. A couple of randomized, double-blind clinical trials have been performed on nanohydroxyapatite toothpaste and nano-hydroxyapatite plus $8 \%$ Arginine in dentine hypersensitivity intervention ${ }^{59,60}$. Table 3 represent clinical trials with polysaccharides based Nano-material.

Table 3: Clinical trials with long-chain polymeric carbohydrate-based nano-material.

\begin{tabular}{lcc}
\hline \multicolumn{1}{c}{ Product } & Clinical trial & Application \\
\hline $\begin{array}{l}\text { Nano-hydroxyapatite } \\
\text { Toothpaste }^{\mathbf{5 9}}\end{array}$ & $\begin{array}{c}\text { Double-Blind } \\
\text { Randomized } \\
\text { Clinical Trial }\end{array}$ & $\begin{array}{c}\text { Dentine } \\
\text { hypersensitivity }\end{array}$ \\
\hline $\begin{array}{l}\text { Nano-hydroxyapatite and 8\% } \\
\text { Arginine }^{\mathbf{6 0}}\end{array}$ & $\begin{array}{c}\text { Double-Blind } \\
\text { Randomized } \\
\text { Clinical Trial. }\end{array}$ & $\begin{array}{c}\text { Dentine } \\
\text { hypersensitivity }\end{array}$ \\
\hline $\begin{array}{l}\text { Nanofibrillar cellulose wound } \\
\text { dressing }^{\text {61 }}\end{array}$ & $\begin{array}{c}\text { Preliminary } \\
\text { Clinical trial }\end{array}$ & Wound healing \\
\hline $\begin{array}{l}\text { Tinidazole functionalized } \\
\text { homogeneous electrospun } \\
\text { chitosan/poly (-caprolactone) } \\
\text { hybrid nanofiber membrane }\end{array}$ & Preliminary & $\begin{array}{c}\text { Chronic } \\
\text { periodontitis }\end{array}$ \\
\end{tabular}

\section{CONCLUSION}

Polymer-based carbohydrate molecules composed of long strings of simple sugars (i.e., monosaccharides or disaccharides) that are covalently linked together by glycosides. They are readily usable and can be used for development, assembling, and modification. Polysaccharides also provide 'natural' alternatives to oil-based synthetic polymers.The creation of nanoparticles from polysaccharides is accomplished by ion or covalent cross-linking, ion-complex, and selfassembly following the grafting of the hydrophobic segments onto the polymer backbone. Polymeric chain length and their charges are an important factor in the selection of appropriate methodology for the development of new nanoparticles.

\section{ACKNOWLEDGEMENTS}

Author extends his thanks and appreciation to the National Center for Public Health to provide necessary facilities for this work.

\section{CONFLICT OF INTEREST}

No conflict of interest associated with this work.

\section{REFERENCES}

1. Wang X, Liu L-H, Ramstrom O, Yan M. Engineering nanomaterial surfaces for biomedical applications. Exp Biol Med 2009; 234(10):1128-1139

https://doi.org/10.3181/0904-MR-134

2. Wang S, McGuirk CM, Ross MB, et al. General and Direct Method for Preparing OligonucleotideFunctionalized Metal-Organic Framework Nanoparticles. J Am Chem Soc. 2017; 139(29):9827-9830. https://doi.org/10.1021/jacs.7b05633

3. Pagis C, Ferbinteanu M, Rothenberg G, Tanase S. Lanthanide-Based Metal Organic Frameworks: Synthetic Strategies and Catalytic Applications. ACS Catal 2016;6(9):6063-6072. https://doi.org/10.1021/acscatal.6b01935

4. Liang R, Wei M, Evans DG, Duan X. Inorganic nanomaterials for bioimaging, targeted drug delivery and therapeutics. Chem Commun 2014; 50(91):14071-14081. https://doi.org/10.1039/C4CC03118K
5. Schaate A, Roy P, Godt A, et al. Modulated synthesis of Zr-based metal-organic frameworks: From nano to single crystals. Chem - A Eur J 2011;17(24):6643-6651. https://doi.org/10.1002/chem.201003211

6. Beg S, Rahman M, Jain A, et al. Nanoporous metal organic frameworks as hybrid polymer-metal composites for drug delivery and biomedical applications. Drug Discovery Today 2016. https://doi.org/10.1016/j.drudis.2016.10.001

7. Keskin S, Kizılel S. Biomedical Applications of Metal Organic Frameworks. Ind Eng Chem Res 2011;50(4):1799-1812. https://doi.org/10.1021/ie101312k

8. Kusindarta DL, Wihadmadyatami $\mathrm{H}$. The role of extracellular matrix in tissue regeneration. In: tissue regeneration In Tech; 2018 https://doi.org/10.5772/intechopen.75728

9. Zheng Y, Monty J, Linhardt RJ. Polysaccharide-based nano-composites and their applications. Carbohydr Res 2015;405:23-32. https://doi.org/10.1016/j.carres.2014.07.016

10. Mokhtarzadeh A, Alibakhshi A, Hejazi M, Omidi Y, Ezzati Nazhad Dolatabadi J. Bacterial-derived biopolymers: Advanced natural nanomaterials for drug delivery and tissue engineering. TrAC - Trends Anal Chem 2016;82(June):367-384 https://doi.org/10.1016/j.trac.2016.06.013

11. Mokhtarzadeh A, Alibakhshi A, Yaghoobi H, Hashemi M, Hejazi M, Ramezani M. Recent advances on biocompatible and biodegradable nanoparticles as gene carriers. Expert Opin Biol Ther 2016; 16(6):771-785. https://doi.org/10.1517/14712598.2016.1169269

12. Rehm BHA. Bacterial polymers: biosynthesis, modifications and applications. Nat Rev Microbiol 2010; 8(8):578-592. https://doi.org/10.1038/nrmicro2354

13. Ismail NA, Mat Amin KA, Razali MH. Novel gellan gum incorporated $\mathrm{TiO}_{2}$ nanotubes film for skin tissue engineering. Mater Lett 2018; 228:116-120. https://doi.org/10.1016/j.matlet.2018.05.140

14. Awad NK, Edwards SL, Morsi YS. A review of $\mathrm{TiO}_{2}$ NTs on Ti metal: Electrochemical synthesis, functionalization and potential use as bone implants. Mater Sci Eng C 2017; 76:1401-1412. https://doi.org/10.1016/j.msec.2017.02.150

15. Cimpean A, Neacsu P, Mazare A, Schmuki P. Attenuation of the macrophage inflammatory activity by $\mathrm{TiO} 2$ nanotubes via inhibition of MAPK and NF-\&amp; kappa;B pathways. Int J Nanomedicine 2015:6455 https://doi.org/10.2147/IJN.S92019

16. Aadil KR, Nathani A, Sharma CS, Lenka N, Gupta P. Investigation of poly(vinyl) alcohol-gellan gum based 
nanofiber as scaffolds for tissue engineering applications. J Drug Deliv Sci Technol 2019; 54:101276. https://doi.org/10.1016/j.jddst.2019.101276

17. Stachewicz U, Qiao T, Rawlinson SCF, et al. 3D imaging of cell interactions with electrospun PLGA nanofiber membranes for bone regeneration. Acta Biomater 2015; 27:88-100. https://doi.org/10.1016/j.actbio.2015.09.003

18. Vashisth P, Pruthi V. Synthesis and characterization of cross-linked gellan/PVA nanofibers for tissue engineering application. Mater Sci Eng C. 2016;67:304-312. https://doi.org/10.1016/j.msec.2016.05.049

19. Habibi Y, Lucia LA, Rojas OJ. Cellulose Nanocrystals: Chemistry, Self-Assembly, and Applications. Chem Rev 2010;110(6):3479-3500. https://doi.org/10.1021/cr900339w

20. Pereira DR, Silva-Correia J, Oliveira JM, Reis RL, Pandit A, Biggs MJ. Nanocellulose reinforced gellan-gum hydrogels as potential biological substitutes for Annulus fibrosus tissue regeneration. Nanomedicine Nanotechnology, Biol Med 2018; 14(3):897-908. https://doi.org/10.1016/j.nano.2017.11.011

21. Anirudhan TS, Rejeena SR. Aminated $\beta$-CyclodextrinModified-Carboxylated Magnetic Cobalt/Nanocellulose Composite for Tumor-Targeted Gene Delivery. J Appl Chem 2014; 2014:1-10. https://doi.org/10.1155/2014/184153

22. Pötzinger Y, Rabel M, Ahrem H, Thamm J, Klemm D, Fischer D. Polyelectrolyte layer assembly of bacterial nanocellulose whiskers with plasmid DNA as biocompatible non-viral gene delivery system. Cellulose 2018; 25(3):1939-1960. https://doi.org/10.1007/s10570-018-1664-z

23. Nguyen D, Hgg DA, Forsman A, et al. Cartilage Tissue Engineering by the 3D Bioprinting of iPS Cells in a Nanocellulose/Alginate Bioink. Sci Rep 2017;7(1):1-10. https://doi.org/10.1038/s41598-017-00690-y

24. Martínez Ávila H, Schwarz S, Rotter N, Gatenholm P. 3D bioprinting of human chondrocyte-laden nanocellulose hydrogels for patient-specific auricular cartilage regeneration. Bioprint 2016;1-2:22-35. https://doi.org/10.1016/j.bprint.2016.08.003

25. Ojansivu M, Rashad A, Ahlinder A, et al. Wood-based nanocellulose and bioactive glass modified gelatinalginate bioinks for 3D bioprinting of bone cells. Biofabrication 2019;11(3):035010. https://doi.org/10.1088/1758-5090/ab0692

26. Wang X, Li Z, Shi T, et al. Injectable dextran hydrogels fabricated by metal-free click chemistry for cartilage tissue engineering. Mater Sci Eng C 2017; 73:21-30. https://doi.org/10.1016/j.msec.2016.12.053

27. Liu Y, Chan-Park MB. Hydrogel based on interpenetrating polymer networks of Dextran and gelatin for vascular tissue engineering. Biomaterials 2009; 30(2):196-207. https://doi.org/10.1016/j.biomaterials.2008.09.041

28. Ding X, Li X, Li C, et al. Chitosan/Dextran Hydrogel Constructs Containing Strontium-Doped Hydroxyapatite with Enhanced Osteogenic Potential in Rat Cranium. ACS Biomater Sci Eng 2019;5(9):4574-4586.

https://doi.org/10.1021/acsbiomaterials.9b00584

29. Pan J, Liu N, Sun H, Xu F. Preparation and Characterization of Electrospun PLCL/Poloxamer Nanofibers and Dextran/Gelatin Hydrogels for Skin Tissue Engineering. Liu X, ed. PLoS One 2014; 9(11):e112885. https://doi.org/10.1371/journal.pone.0112885

30. Ribeiro MP, Morgado PI, Miguel SP, Coutinho P, Correia IJ. Dextran-based hydrogel containing chitosan microparticles loaded with growth factors to be used in wound healing. Mater Sci Eng C 2013; 33(5):2958-2966. https://doi.org/10.1016/j.msec.2013.03.025

31. Nikpour P, Salimi-Kenari H, Fahimipour F, et al. Dextran hydrogels incorporated with bioactive glass-ceramic: Nano-composite scaffolds for bone tissue engineering. Carbohydr Polym 2018; 190 (March):281-294. https://doi.org/10.1016/j.carbpol.2018.02.083
32. Riva R, Ragelle H, des Rieux A, Duhem N, Jérôme C, Préat V. Chitosan and chitosan derivatives in drug delivery and tissue engineering. Adv Polymer Science 2011:19-44. https://doi.org/10.1007/12_2011_137

33. Ma L. Collagen/chitosan porous scaffolds with improved biostability for skin tissue engineering. Biomat 2003; 24(26):4833-4841. https://doi.org/10.1016/S0142-9612(03)00374-0

34. Jin R, Moreira Teixeira LS, Dijkstra PJ, et al. Injectable chitosan-based hydrogels for cartilage tissue engineering. Biomat 2009; 30(13):2544-2551. https://doi.org/10.1016/j.biomaterials.2009.01.020

35. Thein-Han WW, Misra RDK. Biomimetic chitosannanohydroxyapatite composite scaffolds for bone tissue engineering. Acta Biomater 2009; 5(4):1182-1197. https://doi.org/10.1016/j.actbio.2008.11.025

36. Freier T, Montenegro R, Shan Koh H, Shoichet MS. Chitin-based tubes for tissue engineering in the nervous system. Biomat 2005; 26(22):4624-4632. https://doi.org/10.1016/j.biomaterials.2004.11.040

37. Li Z, Ramay HR, Hauch KD, Xiao D, Zhang M. Chitosanalginate hybrid scaffolds for bone tissue engineering. Biomat 2005; 26(18):3919-3928.

https://doi.org/10.1016/j.biomaterials.2004.09.062

38. Martins AM, Eng G, Caridade SG, Mano JF, Reis RL, Vunjak-Novakovic G. Electrically conductive chitosan/carbon scaffolds for cardiac tissue engineering. Biomacromol 2014; 15(2):635-643. https://doi.org/10.1021/bm401679q

39. Liu M, Zheng H, Chen J, Li S, Huang J, Zhou C. Chitosanchitin nanocrystal composite scaffolds for tissue engineering. Carbohydr Polym 2016; 152:832-840. https://doi.org/10.1016/j.carbpol.2016.07.042

40. Kumar A, Rao KM, Han SS. Development of sodium alginate-xanthan gum based nano-composite scaffolds reinforced with cellulose nanocrystals and halloysite nanotubes. Polym Test 2017; 63:214-225. https://doi.org/10.1016/j.polymertesting.2017.08.030

41. Fricain JC, Schlaubitz S, Le Visage C, et al. A nanohydroxyapatite-Pullulan/dextran polysaccharide composite macroporous material for bone tissue engineering. Biomat 2013;34(12):2947-2959.

https://doi.org/10.1016/j.biomaterials.2013.01.049

42. Sharma C, Dinda AK, Potdar PD, Chou CF, Mishra NC. Fabrication and characterization of novel nanobiocomposite scaffold of chitosan-gelatin-alginatehydroxyapatite for bone tissue engineering. Mater Sci Eng C 2016;64:416-427. https://doi.org/10.1016/j.msec.2016.03.060

43. Luo Y, Li Y, Qin X, Wa Q. 3D printing of concentrated alginate/gelatin scaffolds with homogeneous nano apatite coating for bone tissue engineering. Mater Des 2018;146:12-19. https://doi.org/10.1016/j.matdes.2018.03.002

44. Nabavinia M, Khoshfetrat AB, Naderi-Meshkin H. Nanohydroxyapatite-alginate-gelatin microcapsule as a potential osteogenic building block for modular bone tissue engineering. Mater Sci Eng C 2019; 97(November 2018):67-77. https://doi.org/10.1016/j.msec.2018.12.033

45. Li Y, Wang Y, Ye J, Yuan J, Xiao Y. Fabrication of poly( $\varepsilon$-caprolactone)/keratin nanofibrous mats as a potential scaffold for vascular tissue engineering. Mater Sci Eng C 2016; 68:177-183. https://doi.org/10.1016/j.msec.2016.05.117

46. Guo T, Yang X, Deng J, Zhu L, Wang B, Hao S. Keratin nanoparticles-coating electrospun PVA nanofibers for potential neural tissue applications. J Mater Sci Mater Med 2019; 30(1):9 https://doi.org/10.1007/s10856-018-6207-5

47. Hu Y, Chen J, Fan T, et al. Biomimetic mineralized hierarchical hybrid scaffolds based on in situ synthesis of nano-hydroxyapatite/chitosan/chondroitin sulfate/ hyaluronic acid for bone tissue engineering. Coll Surf B Bioint 2017; 157:93-100. 
https://doi.org/10.1016/j.colsurfb.2017.05.059

48. Singh BN, Veeresh V, Mallick SP, et al. Design and evaluation of chitosan/chondroitin sulfate/nano-bioglass based composite scaffold for bone tissue engineering. Int $\mathrm{J}$ Biol Macromol 2019;133:817-830. https://doi.org/10.1016/j.ijbiomac.2019.04.107

49. Aslam MS, Ahmad MS. Worldwide importance of medicinal plants: current and historical perspectives. Recent Adv Biol Med 2016; 02:88. https://doi.org/10.18639/RABM.2016.02.338811

50. Li Q, Niu Y, Xing P, Wang C. Bioactive polysaccharides from natural resources including Chinese medicinal herbs on tissue repair. Chin Med 2018; 13(1):7. https://doi.org/10.1186/s13020-018-0166-0

51. Jin G, Prabhakaran MP, Kai D, Annamalai SK, Arunachalam KD, Ramakrishna S. Tissue engineered plant extracts as nanofibrous wound dressing. Biomat 2013; 34(3):724-734 https://doi.org/10.1016/j.biomaterials.2012.10.026

52. Wang J, Tian L, He L, et al. Lycium barbarum polysaccharide encapsulated Poly lactic-co-glycolic acid Nanofibers: cost effective herbal medicine for potential application in peripheral nerve tissue engineering. Sci Rep 2018;8(1):8669. https://doi.org/10.1038/s41598-018-26837-z

53. Mahboubi M. Elaeagnus angustifolia and its therapeutic applications in osteoarthritis. Ind Crops Prod 2018; 121:36-45. https://doi.org/10.1016/j.indcrop.2018.04.051

54. Hokmabad VR, Davaran S, Aghazadeh M, Alizadeh E, Salehi R, Ramazani A. Effect of incorporating Elaeagnus angustifolia extract in PCL-PEG-PCL nanofibers for bone tissue engineering. Front Chem Sci Eng 2019; 13(1):108119. https://doi.org/10.1007/s11705-018-1742-7

55. Ranjbar-Mohammadi M. Characteristics of aloe vera incorporated poly ( $\varepsilon$-caprolactone)/gum tragacanth nanofibers as dressings for wound care. J Ind Text 2018; 47(7):1464-1477.

https://doi.org/10.1177/1528083717692595
56. Hernandes L, Pereira LM da S, Palazzo F, Mello JCP de. Wound-healing evaluation of ointment from Stryphnodendron adstringens (barbatimão) in rat skin. Brazilian J Pharm Sci. 2010; 46(3):431-436. https://doi.org/10.1590/S1984-82502010000300005

57. Costa LMM, de Olyveira GM, Cherian BM, Leão AL, de Souza SF, Ferreira M. Bionanocomposites from electrospun PVA/pineapple nanofibers/Stryphnodendron adstringens bark extract for medical applications. Ind Crops Prod 2013;41(1):198-202 https://doi.org/10.1016/j.indcrop.2012.04.025

58. He H, Koh MJ, Lee HY, Ang S Bin. Pilot study of a customized nanotextile wet garment treatment on moderate and severe atopic dermatitis: A randomized clinical trial. Pediatr Dermatol 2020; 37(1):52-57. https://doi.org/10.1111/pde.13981

59. Vano M, Derchi G, Barone A, Pinna R, Usai P, Covani U. Reducing dentine hypersensitivity with nanohydroxyapatite toothpaste: a double-blind randomized controlled trial. Clin Oral Investig 2018; 22(1):313-320. https://doi.org/10.1007/s00784-017-2113-3

60. Anand S, Rejula F, Sam JVG, Christaline R, Nair MG, Dinakaran S. Comparative Evaluation of Effect of Nanohydroxyapatite and 8\% Arginine containing toothpastes in managing dentin hypersensitivity: double blind randomized clinical trial. Acta Medica (Hradec Kral Czech Republic) 2017; 60(3):114-119. https://doi.org/10.14712/18059694.2018.3

61. Hakkarainen $\mathrm{T}$, Koivuniemi R, Kosonen M, et al. Nanofibrillar cellulose wound dressing in skin graft donor site treatment. J Control Rel 2016; 244:292-301. https://doi.org/10.1016/j.jconrel.2016.07.053

62. Khan G, Yadav SK, Patel RR, Kumar N, Bansal M, Mishra B. Tinidazole functionalized homogeneous electrospun chitosan/poly ( $\varepsilon$-caprolactone) hybrid nanofiber membrane: Development, optimization and its clinical implications. Int J Biol Macromol 2017; 103:13111326. https://doi.org/10.1016/j.ijbiomac.2017.05.161 